\title{
$100 \mathrm{kV}$ 級雷インパルス電圧による分圧器の 国内持ち回り比較試験
}

$\begin{array}{lllll}\text { 正員 } & \text { 石 } \text { 井 } & \text { 勝 } & \text { (東京大) } \\ \text { 正員 小 山 } & \text { 小 博 } & \text { (東 芝) }\end{array}$

$100 \mathrm{kV}$ Class Intercomparison of Impulse Voltage Dividers in Japan Masaru Ishii, Member (University of Tokyo), Hiroshi Koyama, Member (Toshiba)

Intercomparison tests of dividers for lightning impulse measurement were carried out Japan participated by 12 laboratories. Two resistive dividers, one with $300 \mathrm{kV}$ rating and the other with $1 \mathrm{MV}$ rating, were circulated among the laboratories. The comparison test is one of the methods for checking the uncertainty of a high voltage measuring system, and is proposed in the course of the revision of an IEC standard to incorporate a new idea, that is, the traceability of the uncertainty in high voltage measuring systems.

This paper reports on the determination of the scale factor, evaluation of the unit step response parameters and the comparison tests with lightning impulse voltages at about $100 \mathrm{kV}$. It is demonstrated that the participating 12 laboratories are all capable of realizing the idea in the revision of the IEC standard, that is, to establish traceability. On the other hand, a few problems to be solved in the testing procedures are found, to reduce the scatter in the measured parameters in these tests.

キーワード：分圧器, 雷インパルス, スケールファクタ, 直角波応答, 比較試験

\section{1. まえがき}

高電圧測定における精度は, インパルス電庄分圧器の直 角波応答試験法とともに，これまでIEC Pub. 60 で規定さ れていた。近年，これまで規定になかったトレーサビリティ 一という考え方が国際的に重視されるようになり，それを 実現するための測定系の比較校正に関する研究が，ヨーロ ッパを中心として精力的に行われている(1)2)。トレーサビ リティーとは，電圧，電流などの標準と，測定系の精度を なるべく直接的な手段で関係づけようという考え方であ る。また, インパルス電圧分圧器の研究の進展に伴って, 直角波応答パラメータも，より詳細に規定する必要性が論 じられている。これらの点を積極的に盛り込んだIEC 規 格の改訂案の審議が繰り返され, 現在最終段階にある(3)。 改訂案に扔ける技術的な問題点は，雷インパルス電圧の測 定にほとんど集中して扔り，国際的な比較試験の研究も， 雷インパルス電圧の測定系を中心に行われている。

1990 年 4 月, 電気学会に打いて第 2 種の委員会として, インパルス測定精度向上協同研究委員会が組織された ${ }^{(4)}$ 。 1991 年 7 月〜 9 月にかけて委員の所属する 4 機関が, ド イッ,オーストラリア, 日本, 中国の間で実施された, ド イツ連邦物理工学研究所 (PTB) 所有の 2 台の抵抗分压
器による，100 kV 級の雷インパルス電圧における国際持 ち回り試験に参加した。この国際持ち回り比較試験では, 測定系の分圧比の測定, 直角波応答測定および比較試験 が，IEC 規格改訂案を念頭において実施された ${ }^{(5)}$ 。その後 すぐに, 委員の所属している日本国内の 12 機関において, 1991 年 9 月から約 1 年間加けて同様の持ち回り比較試験 が実施された。この持ち回り比較試験では，同一の項目に ついて，各機関で測定を実施し結果を比較する。その目的 は，各機関の技術レベルに関する知見，および試験項目， 実施にあたっての細目の妥当性を検討するところにある。 後者については，ヨーロッパで実施された持ち回り比較試 験(2)のものを基本とした。その結果，日本のこの分野に おける技術レベル，IEC規格改訂案における問題点など が明らかになったので報告する。

\section{2. 分圧器の詳細}

2 台の異なる特性のシールド付き抵抗分圧器を持ち回り して測定が実施された。共通に持ち回わった部品は 2 台の 分圧器, 高電圧リード線, 測定ケーブル, 整合抵抗であ る。その他の球ギャップ, 減衰器, 計測器, 記録装置など は, 各機関所有のものを用いている。

〈2・1〉 分圧器 $\boldsymbol{A}$ 国内比較試験において基準分圧器 


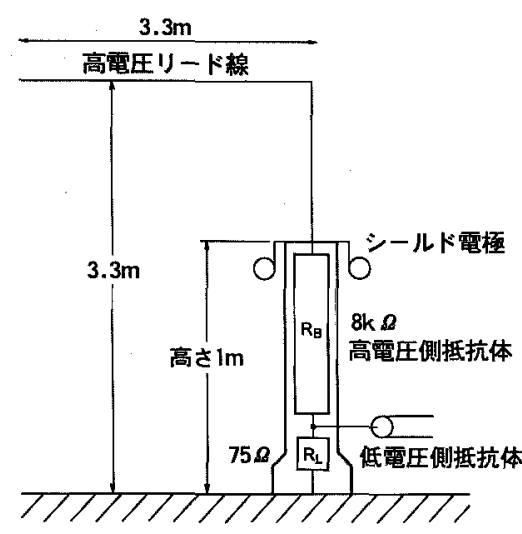

図 1 分圧器 $A$ の測定系構成

Fig. 1. Structure of impulse voltage divider $A$.

とした分圧器 $A$ は，PTB から購入したものである。分圧 器はヨーロッパや 4 箅国間で既に実施された $100 \mathrm{kV}$ 級国 際持ち回り比較試験に使われたうちの1台（定格 300 $\mathrm{kV})$ とほほ同じ特性をもつ。図 1 k分圧器 $A$ の構成を示 す。分圧器本体の高さ㹥約 $1 \mathrm{~m}$ で, 高電圧部の構成は, 高電圧側に小型のシールド電極が取り付けられており, 約 $8 \mathrm{k} \Omega$ の折返し巻きの抵抗体で構成されている。低電圧部 は, 分圧器 $A$ に専用の同軸ケーブル $(25 \mathrm{~m})$ のインピー ダンスに合わせて，並列接続した抵抗体（合成抵抗值 75 凤）で整合がとられている。また，高電圧側の回路に，制 動抵抗を接続しないで測定したときの応答時間が 0 になる ように調整されている (PTBでの測定)。高電圧リード線 は, 次に述べる供試分圧器 $B$ の高さに合わせ, かつ測定 系の幾何学的形状が共通となるょう, 水平方向の長さが約 $3.3 \mathrm{~m}$, 垂直方向の長さが約 $2.3 \mathrm{~m}$ で直径 $2 \mathrm{~cm}$ のステン レス鋼製パイプを作製し, 分圧器に付属させた。更に, 高 電圧リード線の入力部に挿入できる構造の $200 \Omega$ の制動抵 抗を用意した。

制動抵抗は，元来，ステップ応答波形の振動を抑える目 的で使用されていたが，裁断波の波高值と測定誤差を問題 にする場合には，整定時間 $T_{s}$ が許容範囲内にあれば，才 一バシュートが大きくても差し支えないため, 近年は用い られなくなってゆく傾向にある。今後, 制動抵抗は, 整定 時間, オーバシュートの調整のために用いられるようにな ると思われる。分圧器 $A$ も制動抵抗無しが標準の状態で あり，制動抵抗はオプションとしてPTBが用意したもの である。

$\langle 2 \cdot 2\rangle$ 分圧器 $\boldsymbol{B}$, 供試器としての分圧器 $B$ は, シ ールド付き抵抗分圧器である。高電圧部は, 長さが $1 \mathrm{~m}$ で抵抗值が約 $3 \mathrm{k} \Omega$ の抵抗体を 3 本直列に接続して構成し た。低圧部は $80 \Omega$ の巻線抵抗体を 8 本放射状に並列配置 し，合成抵抗值は $10 \Omega$ とした。測定用同軸ケーブルのイ ンピーダンス $75 \Omega$ と整合をとるために，低圧部と同じタ イプの巻線抵抗体 $65 \Omega$ を, 高圧部と低圧部の結合点と測 定ケーブル接続用端子との間に接続した。図 2 に分圧器 $B$ の構成を示す。高電圧部にはリング状シールド電極

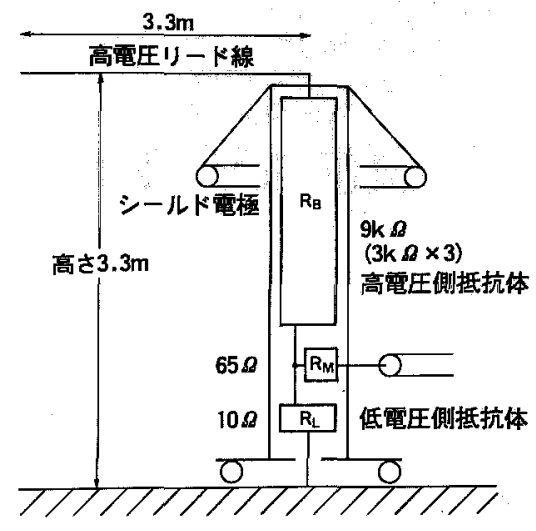

図 2 分圧器 $B$ の測定系構成

Fig. 2. Structure of impulse voltage divider $B$.

（リング直径 $1.5 \mathrm{~m}$ ) が取り付けられている。シールド電 極は分圧器 $B$ の高電圧側の抵抗体の電位分布の改善と, 抵抗体の漂遊容量の補償をして応答特性を改善するために 設けた。分压器 $B$ には水平方向に長さ $3.3 \mathrm{~m}$ の高電圧り ード線と測定ケーブルを付属させ，制動抵抗は用意しなか った。

\section{3. 分圧比の決定}

ほとんどの機関では分圧器と一緒に供給された整合抵抗 $75 \Omega$ を付けた構成で, 分圧器の各構成要素の抵抗值を直 流電圧で測定し，分圧比を計算した。持ち回り比較試験中 にこの整合抵抗が破損したため，すべての機関が同一条件 のもとで分圧比を測定することができなかった。このた め，各抵抗体の測定値のばらつきから，分圧比の測定誤差 を検定する。

分圧器 $A$ および分圧器 $B$ の高電圧側, 低電圧側の各々 の抵抗値の測定結果は $0.15 \%$ 以内の差で一致した。これ は抵抗值測定器の誤差に相当する值である。また，幾つか の機関では交流電圧でも分圧比を測定し，0.1\%以内の詋 差で一致することが確かめられている。従って，抵抗值測 定器の校正が十分に行われていれば，抵抗值を基に計算さ れる分圧比は測定器誤差に近い值で決定できることが確か められた。

\section{4. 直角波応答波形の測定}

1 機関を除いて図 3 に示す IEC 規格案の推奨する回路 構成により, 後述する比較試験時と同じ測定系の構成で直 角波応答の測定を実施した。多くの機関が用いた直角波発 生器は, 主に数百 $\mathrm{V}$ の直流電圧電源と水銀リレーで構成 され, 分圧器と等しい高さに配置されている。測定系には あらかじめ直流電圧を印加しておき，水銀りレーにより短 絡接地することで急峻な立下りの直角波電圧を測定系に印 加する。二つの機関においては, 市販の直角波発生器を用 いて測定を実施した。また, 分圧器から直角波発生器まで の接地系には幅 $1 \mathrm{~m}$ 以上の銅板を使用している。

図 4 に測定波形例を示す。ほとんどの機関では図 4 に近 


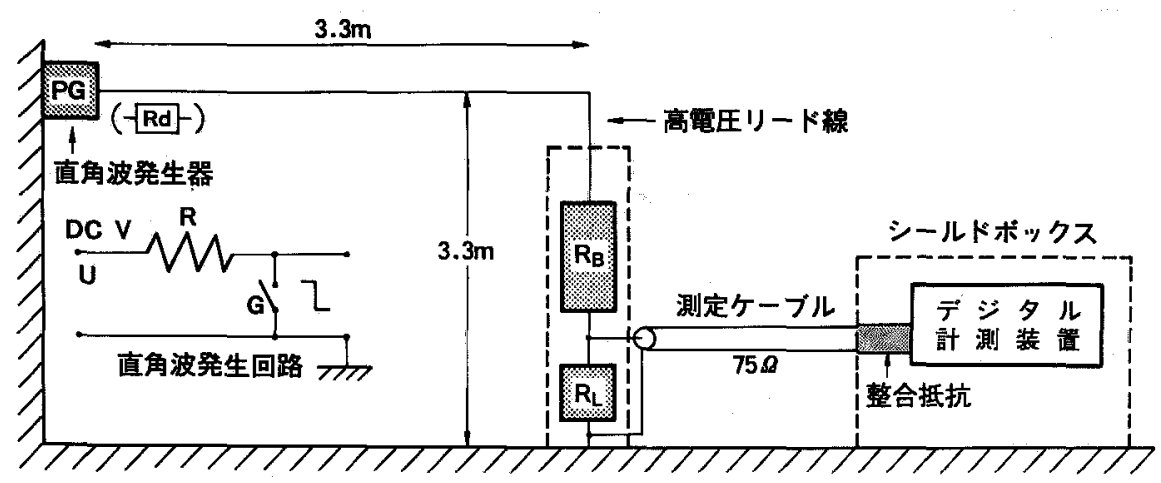

図 3 直角波応答測定回路

Fig. 3. Measuring circuit for unit step response.

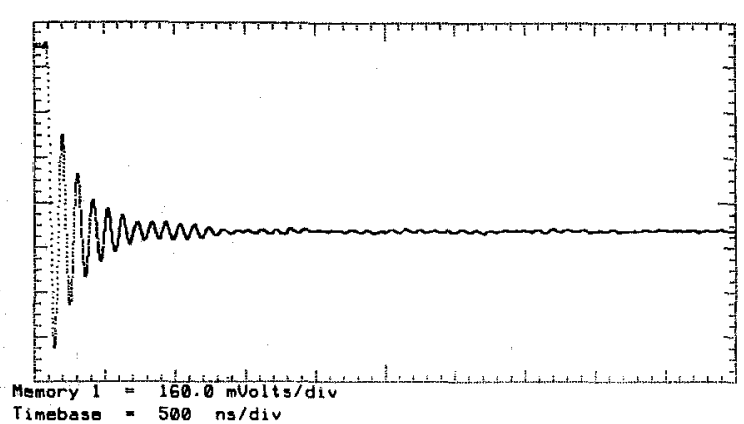

(a) 分圧器 $A(R d=0 \Omega)$

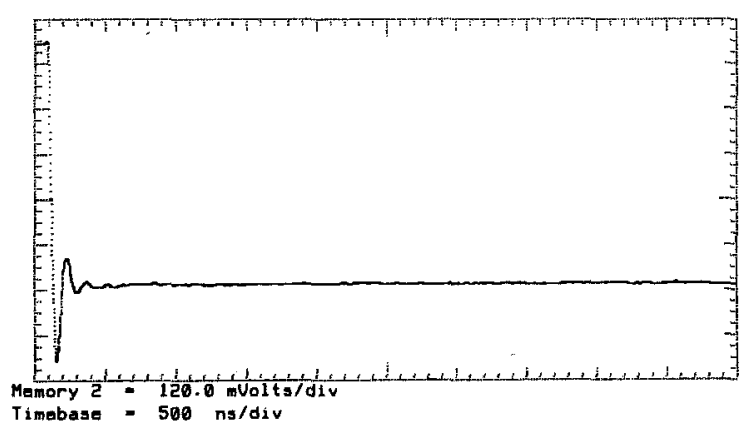

(c) 分圧器 $B$ (高圧シールド有)



(b) 分压器 $A(R d=200 \Omega)$

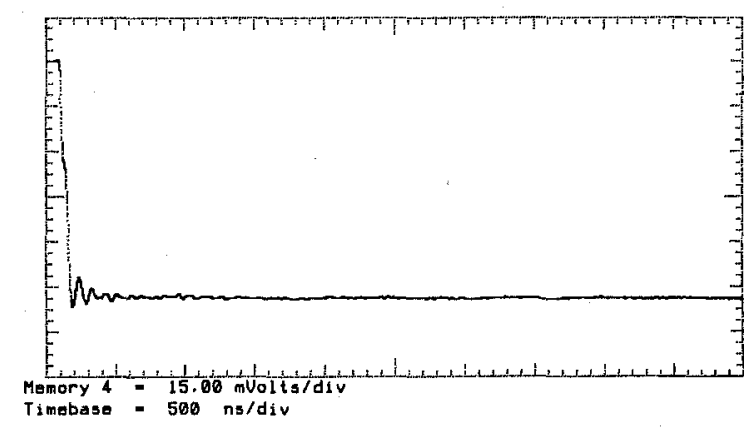

(d) 分圧器 $B$ (高圧シールド無)

図 4 直角波応答波形例

Fig. 4. Examples of unit step response waveforms.

い波形が得られている。測定波形を正規化した波形から， 図 5 に示される定義(3)に涏って応答パラメータを各機関で 求めた。分圧器 $A$ と分圧器 $B$ に関する五つの応答パラメ 一夕について，12の機関による測定值の平均值および標 準偏差をまとめたものを表 1 に示す。各機関で算出された 応答パラメータは，手計算あるいはコンピュータによる計 算で決定された。

コンピュータによる計算で評価されたパラメータのなか には，他の数值とかけ離れた值が報告されたため，誤りが 発見できた例があった。波形パラメータの計算をコンピュ ータで行う際には，細心の注意が必要である。

分圧器 $A$ に制動抵抗を挿入しない場合は，図 4(a)に 示すように大きく振動する測定波形が得られた。応答時間 $T$ および整定時間 $T_{s}$ については標準偏差が大きい。部分 応答時間 $T_{\alpha}$ やオーバシュート率 $\beta$ については, 応答時間
$T$, 整定時間 $T_{s}$ に比べると標準偏差が小さく各機関間の 一致度は高かったといえるだろう。

分圧器 $A$ は制動抵抗を挿入した場合は, (b)図に示す 上うに測定波形の振動はかなり小さくなり，応答時間 $T$ および部分応答時間 $T_{a}$ は制動抵抗がない場合より増加し

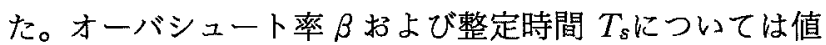
も標準偏差も小さくなった。制動抵抗を㨉入することで応 答特性が劣ってくると, 測定系に及ほすす各害験室固有の未 知の要素の影響が小さくなり, 各機関での測定波形は似て くるようである。

分圧器 $B$ に高電圧シールドが有る場合は, (c)図に示 すような振動の大きい測定波形が得られた。この場合も， 整定時間 $T_{s}$ のばらつきが大きい。応答時間 $T$ については 分圧器 $A$ に比べると劣っているが, 部分応答時間 $T_{\alpha}$ やオ 一バシュート率 $\beta$ については, 分圧器 $A$ に制動抵抗を挿 




図 5 直角波応答パラメータの定義(3)

Fig. 5. Definition of unit step response parameters.

表 1 直角波応答パラメータ

Table 1. Unit step response parameters.

\begin{tabular}{|c|c|c|c|c|c|c|}
\hline \multicolumn{2}{|c|}{ 分压器 $A$} & $\begin{array}{c}T \\
(\mathrm{~ns})\end{array}$ & $\begin{array}{c}T_{\alpha} \\
\text { (ns) }\end{array}$ & $\begin{array}{c}T_{0} \\
\text { (ns) }\end{array}$ & $\begin{array}{c}\beta \\
(\%)\end{array}$ & $\begin{array}{c}T_{s} \\
\text { (ns) }\end{array}$ \\
\hline \multirow{2}{*}{$\begin{array}{l}R_{d} \\
0 \Omega \\
\end{array}$} & 平均值 & 3.1 & 9.7 & 0.4 & 58.2 & 346.9 \\
\hline & 標準偏差 & 6.5 & 1.8 & 0.2 & 10.1 & 189.4 \\
\hline \multirow{2}{*}{$\begin{array}{c}R_{d} \\
200 \Omega\end{array}$} & 平均値 & 10.7 & 15.3 & 0.4 & 29.1 & 186.3 \\
\hline & 標準偏差 & 5.0 & 2.2 & 0.3 & 7.8 & 133.2 \\
\hline \multicolumn{2}{|c|}{ 分区器 $B$} & $\begin{array}{c}T \\
\text { (ns) }\end{array}$ & $\begin{array}{c}T_{a} \\
(\mathrm{~ns})\end{array}$ & $\begin{array}{c}T_{0} \\
(\mathrm{~ns})\end{array}$ & $\begin{array}{c}\beta \\
(\%)\end{array}$ & $\begin{array}{c}T_{s} \\
\text { (ns) }\end{array}$ \\
\hline \multirow{2}{*}{$\begin{array}{c}\text { シ高圧 } \\
\text { ジ } \\
\text { 有 }\end{array}$} & 平均 值 & 17.8 & 16.6 & 0.4 & 39.1 & 427.1 \\
\hline & 標準偏差 & 5.3 & 2.1 & 0.4 & 5.4 & 337.4 \\
\hline \multirow{2}{*}{$\underset{\substack{\text { 高圧 } \\
\text { 無 }}}{ }$} & 平均 值 & 46.7 & 41.2 & 0.1 & 5.0 & 263.6 \\
\hline & 標準偏差 & 7.0 & 2.9 & 0.1 & 2.1 & 149.8 \\
\hline
\end{tabular}

$R_{d}$ : 制動抵抗を示す (分圧器 $B:$ 制動抵抗無)

入した場合に近い值であった。また約半数の機関では，分 圧器 $B$ の高電圧シールドを外した場合についても測定し, (d) 図に示すような振動の小さい測定波形が得られた。応 答時間などの值は倍以上になり，応答特性はかなり劣って しまうため，応答特性に及ぼす高電圧シールドの影響が強 い分圧器といえる。

全体を通じ，整定時間 $T_{s} に は ，$ 異なる測定環境が大き く影響している。例えば，同じ機関でも測定室のみを代え た場合に，影響があったという報告があった。また使用し た記録装置の周波数特性による応答特性への影響を調べた 例（200 MHz と $25 \mathrm{MHz}$ ) では，帯域幅が狭い場合はオ 一バシュート率 $\beta$ を減少させる傾向にあることなどが観 測されている。

\section{5. 比較試 験}

〈5・1〉 方 法 雷インパルス電圧波形での比較試 験は, 分圧器 $A$ と分压器 $B$ を, 対称な $Y$ 形に配置し, 図 6 の回路で実施した。高電圧リード線の接合点には $\phi 250 \mathrm{~mm}$ の球ギャップを垂直に配置して（幾つかの機関 ではこれより小さい球ギャップを用いた）裁断波を発生で きる構成をとっている。印加電圧波形としては, 標準雷人 ンパルス電圧波形 $(1.2 / 50 \mu \mathrm{s})$ と裁断波電圧波形（裁断 時間 $T_{\mathrm{c}}$ の目標值 $\left.1.5,1.0,0.5 \mu \mathrm{s}\right)$ で, 印加電圧の波高 值は約 $100 \mathrm{kV}$ （幾つかの機関では約 $120 \mathrm{kV} て ゙$ 実施）を 標準とした。

分圧器からの出力電圧は, 各機関で手持ちの整合抵抗を かねた減衰器を接続して，1台のディジタル計測器の 2 チ ヤネルを使用して同時に記録している。1機関においての み, 2 台のディジタル計測器を各々の測定系に接続して同 時に測定している。多くの機関では, 計測器のチャネル間 誤差を最小限にするために，測定途中にチャネルを交換し たり，ステップ電圧などを用いて計測器の校正を実施し, 測定データに補正を施している。測定は 10 回以上繰り返 し, その平均値を各機関での測定值として算出した。

比較試験の実施に先立ち, IEC 規格改訂案に従って, 測定系への誘導障害のチェックを行った。比較試験時の実 回路と幾何学的配置を変えないまま,一方の分圧器からの 測定ケーブルの分圧器側を短絡接地し, 比較試験時の電圧 を印加して測定系への誘導電圧を測定した。3機関ではそ の誘導電圧は, 測定信号電圧に対して $1 \%$ の IEC 規格改 訂案における許容值を若干超えたが，他の機関は $1 \%$ 以下 の值であったことを確認している。最大入力電圧の小さい ディジタル計測器を用いても, 今回の比較試験のような条 件のもとでは，特別な対策を施さなくとも誘導は十分小さ く抑えられることがわかった。

〈5.2〉 結 果 図 7 には, 分圧器 $A$ に制動抵抗を 挿入しない場合の裁断時間 $T_{c}$ に対する, 分圧器 $A$ を基準 とした分圧器 $B$ の波高値差 $\delta U$ おょび波頭長時間差 $\delta T$ について，各機関の測定値およびその平均值を示す。標準 雷インパルス波形での測定結果は, $2.5 \mu \mathrm{s}$ のころに記し てある。図中のハッチング部分は IEC 規格案(3) の許容限 界を示している。各機関の算出値は，白抜きの丸印で重なら 




図 6 比較試験回路

Fig. 6. Comparison test circuit.

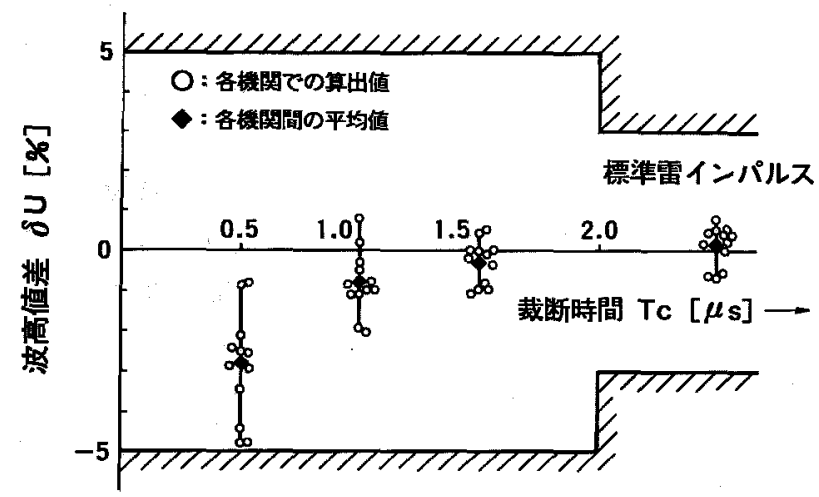

(a) 波高值差

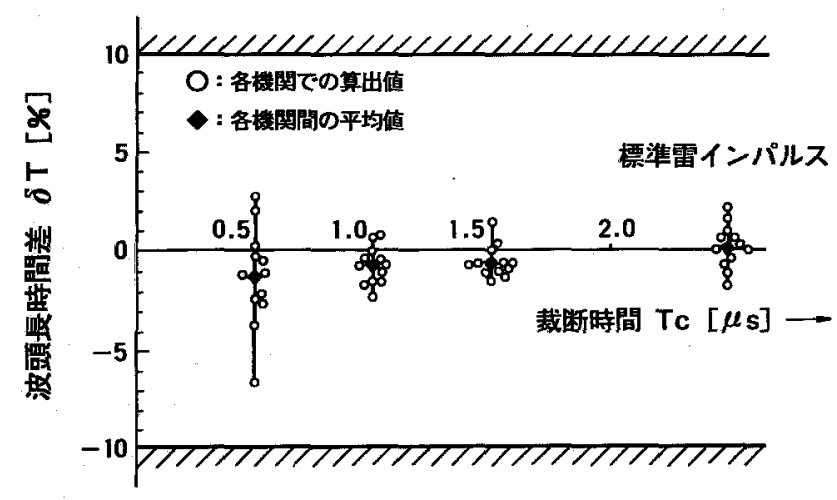

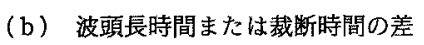

図7 分圧器 $A, B \sigma$ 比較試験結果（制動抵抗 なしの分圧器 $A$ が基準)

Fig. 7. Result of comparison test between dividers $A$ and $B$ (peak voltage difference $\delta U$ and front time difference $\delta T$ of divider $B$ compared with divider $A$ without $R_{d}$ ).

ないようにすべてプロットし，各機関の平均値は塗りつぶ しのひし形印でプロットしてある。(a)図に示す波高值差 $\delta U に つ い て は ，$ 標準雷インパルス波形では，す心゙ての機 関において $\delta U$ が $1 \%$ 以内の值であった。その平均值は 約 $0.1 \%$ であり，標準偏差は約 $0.5 \%$ 小さな值で，各機 関間のばらつきは活とんどなかった。裁断波形について は， $T_{c}=1.5 \mu \mathrm{s}$ では，標準雷インパルス波形の場合と同

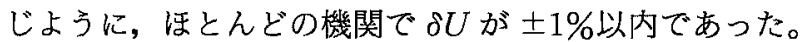

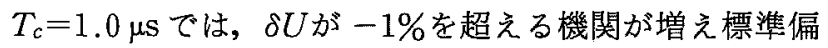
差も大きくなる。 $T_{c}=0.5 \mu \mathrm{s}$ では, $\delta U$ の平均值は約 -2.8\%であり，標準偏差は1\%を超えてかなり大きかっ たが,すべての機関でIEC規格案の許容限界である ー5\%以内の值であった。

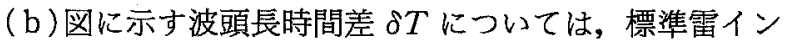
パルス波形では $\delta T$ の平均值は約 $0.2 \%$ 小さいが, 標準 偏差は $1 \%$ を超えてばらつきが大きかった。各裁断波形に ついては, 裁断時間が短くなるに従ってばらつきは大きく なるが, $\delta T$ の平均值はー $2 \%$ 以内で標準偏差も $3 \%$ 以内で あった。

このように裁断時間 $T_{c}$ が短くなるに従い, 波高值差 $\delta U$ ，波頭長時間差 $\delta T$ および各機関間のばらつきが大き くなる。この傾向は，以下で述べるように，比較試験にお ける分圧器の組合せが異なっても変わらない。

図 8 には, 分圧器 $A$ に制動抵抗を挿入した場合の裁断 時間 $T_{c}$ に対する, 分玨器 $A$ を基準とした分圧器 $B$ の波

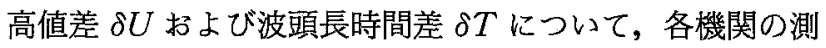
定值およびその平均值を示す。制動抵抗を入れることで分 圧器 $A$ の応答特性が悪くなり, 分圧器 $B$ との特性の差が 小さくなるため, 図7 の場合よりも差が減少している。図 8 (a)に示す波高值差 $\delta U$ については, 標準雷インパルス 波形および裁断波形の $T_{c}=1.5 \mu \mathrm{s}, 1.0 \mu \mathrm{s}$ で $\delta U$ がー $1 \%$ を超える機関が幾つかあり若干ばらついているが，その平 均值は分圧器 $A$ に制動抵抗がない場合とほとんど同じで 小さな值であった。 $T_{c}=0.5 \mu \mathrm{s}$ では， $\delta U$ の平均值は約 -1\%であり，值としては小さいが，標準偏差は $1 \%$ 超 えてばらつきが少し大きかうた。(b)図に示す波頭長時間

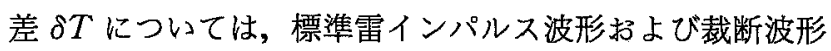
の $T_{c}=1.5 \sim 0.5 \mu \mathrm{s}$ で $\delta T$ の平均值は $\pm 0.2 \%$ 以内でかな り小さい值であった。標準偏差については $T_{c}=0.5 \mu \mathrm{s} て ゙$ 1\%を超えたが，他の場合は 1\%以内の值で，各機関間の ばらつきは小さかった。

2 機関においては, 分圧器 $B$ の高電圧シールドを外し, 


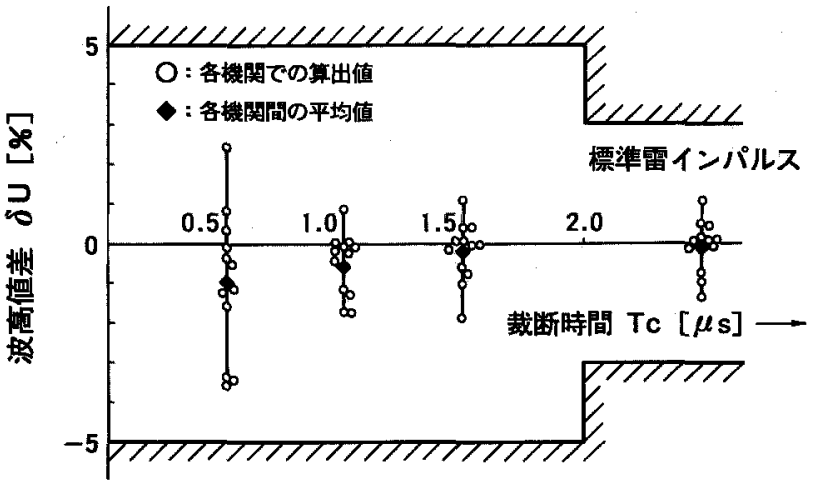

(a) 波高値差

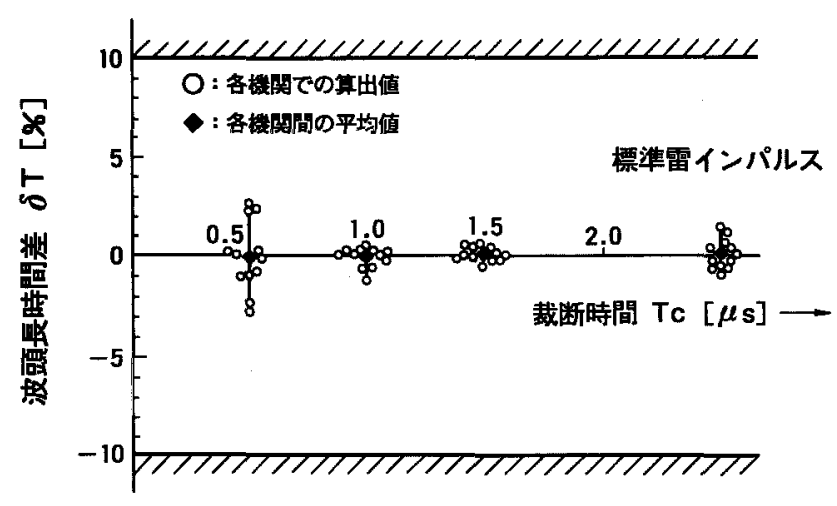

（b）波頭長時間または裁断時間の差

図 8 分圧器 $A, B O$ 比較試験結果（制動抵抗 ありの分圧器 $A$ が基準)

Fig. 8. Result of comparison test between dividers $A$ and $B$ (peak voltage difference $\delta U$ and front time difference $\delta T$ of divider $B$ compared with divider $A$ with $R_{d}$ ).

分圧器 $A$ に制動抵抗を挿入しない場合の比較試験を実施 している。この場合, 分圧器 $B$ の応答特性が悪くなるた め, 両者の差は被測定波形の裁断時間が短いほど増大す る。標準雷インパルス波形については, 波高值差 $\delta U$ は $\pm 0.3 \%$ 以の值であった。裁断波形については, 裁断時 間 $T_{c}$ が小さくなるに従って $\delta U$ は大きく増加する。 $T_{c}=$ $0.5 \mu \mathrm{s}$ では 2 機関とも IEC 規格案の許容限界である $-5 \%$

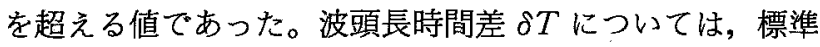
雷インパルス波形抢よび裁断波形 $\left(T_{c}=1.5 \sim 0.5 \mu \mathrm{s}\right)$ に おいて， $T_{c}$ が小さくなるにつれて $\delta T$ は增加するが， 2 機関とも IEC 規格案の許容限界である $-10 \%$ 以内の值で あった。

\section{6. 検 討}

〈6・1〉単独の測定システムの試験 今回持ち回りし た抵抗分圧器のように, 直流電圧あるいは交流電圧による 抵抗値の測定から分圧比が計算できる剆定系においては, 抵抗值測定器のもつ誤差に近い誤差で分圧比の決定を行う ことが十分可能である。

直角波応答形の測定条件をかなり詳細に規定したにもか かわらず，特に整定時間 $T_{s}$ のばらつきが大きかった。こ
れには技術的な問題だけでなく，実験室の条件が影響して いる可能性がある。その場合の同一の分圧器を使用して, 同じ試験回路を IEC 規格改訂案に沿って構成しても，実 験室が異なると，測定システムとしての特性は異なること になる。IEC 規格改訂案は「測定システム」を対象とし ているため,このことによって不都合は生じないが, 同じ 分圧器を購入しても, 同じ特性の測定系が構成できるとは 限らないことに注意しなければならない。

整定時間 $T_{s}$ が過大な場合には，制動抵抗を入ること によって対処できるが, システムの応答速度は遅くなる。 $T_{s}$ 以外のパラメータのばらつきはそれほど大きくはない。 このばらつきは, 応答速度が遅くなると, 一般に減少する 傾向にある。また各応答パラメータの算出方法はコンピュ ータを用いて計算した場合や，手計算した場合など各機関 で異なるため，これもばらつきの生じる要因の一つになっ ている。例えばコンピュータによる計算では, 正規化した 規約点の微小な変化が大きく計算結果に影響するという報 告があった。

分圧器 $A$ は制動抵抗を入れない場合の応答時間がほほ 0 のため, 比較対象の分圧器の実力を測定するうえでは適 切であったといえる。ただし，IEC規格案の要求する基 準測定系 $(\mathrm{RMS})^{(3)}$ として $T_{s}$ を規定值内に抑えるために は，多くの機関で制動抵抗を挿入する必要があった。この ように適当な対策を施す事により, 分圧器 $A$ を用いて基 準測定系を構成する事が可能であった。

〈6・2〉比較試験 比較試験において, 二つの測定系 の応答時間の差の平均值から理論的に予想される波高值差 は, $0.5 \mu \mathrm{s}$ の裁断波の測定に際しては, 図 7 の場合で $3 \%$ ，図 8 の場合で約 1.5\%程度であり，それぞれの比較 試験における差の平均值とほぼ一致している。従って, 平 均值を見る限りでは, 直角波応答と比較試験の間には対応 が見られるが，2\%以上に及ぶばらつきが見られるのは問 題である。同じ $0.5 \mu \mathrm{s}$ の裁断波については, 裁断時間の 測定值の差のばらつきも大きいが，これはディジタル測定 に際してのサンプル時間間隔 $20 \mathrm{~ns}$ の場合, データの間隔 は被測定時間 $0.5 \mu \mathrm{s}$ の $4 \%$ になる。

波高值差にばらつきが生じた原因は幾つか考えられる。 ディジタル波形記録装置のチャネル間の特性差が影響する ため，各機関で独自に校正を実施した。チャネル間の特性 差は, 応答特性の面にはあまり影響しないと思われるた め，この要因による波高值差は裁断時間にはほとんど関係 しないであろう。従って,この要因による波高值差は, 今 回の持ち回り比較試験では，土1\%に収まって扔り，あま り問題はない。しかしながら，より高い精度を要求する場 合には, ディジタル計測器の校正方法や, 雑音除去のため の波形処理方法などについて, 今後更に検討する必要があ る。

今回の比較試験実施上の困難な点として，インパルス電 圧発生器の負荷が, 2 台の抵抗分圧器により重くなるため に，出力波形の調整がやっかいなことがあった。このた 
め, 各機関のインパルス電圧波形には，若干の差があって も不思議ではない。裁断条件の差による裁断時間のばらつ きもあったと思われる。これらが比較試験結果のばらつき の要因の一つとなっていることも考えられるが，比較試験 という試験法自体が，これらの影響を軽減するように働く ので，これらが主要な原因とは考えにくい。

波高值差のばらつきにかなり影響しているかも知れない のは, 測定ケーブルとディジタル計測器の間に挿入される 隇衰器の応答時間である。測定システムの直角波応答性 は，これを含まないで測定されているが，比較試験に際し ては, 分圧器出力と, ディジタル計測器の入力レベルを合 わせるため, 減衰器が挿入されているのが普通である。今 回の持ち回り試験では，ヨーロッパで実施された持ち回り 試験と同じく，その応答特性を確認することを義務づけて いないが，今後は測定項目に加える必要がありそうであ る。

最後に, 実験室自体が測定系の直角波応答特性, 特に整 定時間に影響することがわかったが, これと比較試験結果 との関係は, 今のところ不明である。持ち回りに供した分 圧器は 2 台ともそう大きくなかったため, 測定への近接障 害物の及涩す影響は小さかったと考えられる。しかし，大 形の汎用分圧器を含む測定系を対象とする場合に備えて, 近接障害物の影響も今後検討していく必要がある。

\section{7.むすび}

日本国内の 12 の機関が参加して，2 台の抵抗分圧器を 供試器として, $100 \mathrm{kV}$ レベルでの雷インパルス電圧測定 に関する持ち回り試験を行った。その結果，雷インパルス 電圧測定技術における日本の平均的なレベルは，ヨーロッ パ各国と同程度の水準にあることがわかった。トレーサビ リティーを確立しょうとする IEC 規格改訂案の意図は, このレベルの機関においては一応実現されるとみてよい。 しかし, 各機関それぞれの測定器, 測定環境の差による測 定結果のばらつきをいっそう減少させるため，直角波応答 試験，比較試験の手順をより厳密に規定する必要がある。 これらの点に留意しつつ，より実用的な高い電圧における 測定システムの校正方法を検討していきたい。

日本国内の 12 機関が参加して分圧器 2 台を含む測定系 を持ち回わり，直角波応答測定や比較試験が実施された。 1 機関 1 箇月という短い期間で準備も十分できなかったに もかかわらず, 価值のあるデータが得られた。これらのデ

ータは，次のステップの実用電圧レベルである数 MV 級 の比較試験への有効な情報となった。今回の国内持ち回り 比較試験に協力してくださった，インパルス測定精度向上 協同研究委員会に参加している日本工業大学，(株)日立製 作所, 三菱電機 (株), 財団法人電力中央研究所, 富士電機 (株), 日本ガイシ(株), (株) 明電舎, 古河電気工業(株), 工学院大学, 日新電機 (株), (株) フジクラの各委員に樑く 感謝いたします。

(平成 5 年 6 月 1 日受付)

\section{文 献}

(1) T. R. Mc Comb, R. C. Hughes, H. A. Lightfoot, K. Schon, R. Schulte, R. McKnight \& Y. X. Zhang: "International comparison of HV Impulse measring systems", IEEE Trans. Power Delivery, 4, No.2 (1989-4)

(2) A. Boamy, G. Rizzi, A. W. van, R. C. Hughes, A. Vaz, F. Garnaho \& K. Schon: "International Comparison of $\mathrm{HV}$ Impulse Dividers", 7 th ISH, Dresden, 61. 07(1991)

(3) IC Committee Draft: "High Voltage Test Techniques Part 2: Measuring Systems", TC 42 (S) 82(1992)

（4）調查研究委員会レポート:「インパルス測定精度向上協同研究委 員会」, 電学論 $\mathrm{B}, 112,1160$ (平 $4-12$ )

(5) J. Rungis, M. Ishii, Y. Cunyi \& K, Schon: "Intercomparison of impulse dividers from PTB in Australia, Japan and China", 8 th ISH, Yokohama

石 井 勝 (正員) 1949 年 3 月 11 日生。1976 年 3 月東京


大学大学院工学系研究科博士課程修了。同年 4 月同大助教授, 生産技術研究所勤務, 1992 年 7 月同教授, 現在に至る。工学博士。主として, 系統絶縁, 自然雷，高電圧現象の測定に関する 研究に従事。1988 年度日本大気電気学会学術研 究賞受賞。1989,90 年度電気学会東京支部評議 員。電気設備学会, 日本大気電気学会, 日本気 象学会, 静電気学会, IEEE Senior Member。

小山

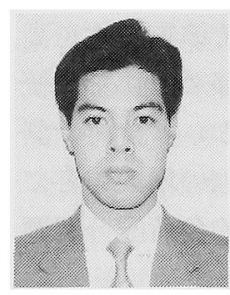

（正員） 1962 年 8 月 9 日生。1986 年 3 月法政大 学工学部電気工学科卒業。同年 4 月(株) 東芝入 社。高電圧絶縁技術に関する研究に従事。 